\title{
Fifth Grade Students' Logical Thinking in Mathematics
}

\author{
Rani Syafitri ${ }^{1}$, Zetra Hainul Putra ${ }^{1 *}$, Eddy Noviana ${ }^{1}$ \\ ${ }^{1}$ Department of Elementary Teacher Education, Faculty of Teacher Training and Education, \\ University of Riau, Pekanbaru, Indonesia \\ *zetra.hainul.putra@lecturer.unri.ac.id
}

Accepted: July $28^{\text {th }}, 2020$

\begin{abstract}
The purpose of this study was to investigate fifth-grade students' logical thinking in mathematics. Their logical thinking skills were categorized based on five levels, namely very low, low, medium, high and very high. This study used descriptive quantitative method, and it was conducted with 123 fifth-grade students from a public elementary school in Pekanbaru, Riau, Indonesia. The instruments used to collect data were logical thinking ability tests consisting of short answer tasks and mathematical reasoning for the given answers. The results of this study indicated that students have very low logical thinking within the average score of $22.76 \%$. More than half of students could not give correct answers to the given tasks and also could not provide reasoning to their answers. The implication of this study is that teachers, teacher educators, curriculum developers, and government need to develop learning instruction that support students' logical thinking in facing challenges in $21^{\text {st }}$ century life.
\end{abstract}

Keywords: descriptive quantitative; logical thinking; mathematical reasoning; twentieth first century life.

\section{INTRODUCTION}

Students need competencies and survival skills in facing life, the world of work, and citizenship in the 21st century. Wagner (2010) has identified seven 21st century skills, namely, critical thinking and problem solving, collaboration across networks and leading by influence, agility and adaptability, initiative and entrepreneurialism, effective oral and written communication, accessing and analyzing information, and finally curiosity and imagination. All of these skills should be possessed by students so that they can face life challenges in the 21st century.

The 21st Century skills must be explicitly taught to students in elementary school (Larson \& Miller, 2011). The 21st-century learning has the fundamental principle that learning must be student-centred, collaborative, contextual, and integrated with society. Logical thinking is one form of developing critical thinking skills, and it is part of the process of using reasoning consistently to draw a conclusion (Syafmen \& Marbun, 2014: 2). Students 
need this competence in solving complex and diverse real-life problems. A study conducted by Andriawan (2014) shows that junior high school students' logical thinking skills are still in the low category, unable to plan problem-solving steps, have not been able to provide arguments and conclude correctly. This situation leads us to some questions related to elementary school students' logical thinking. Do they also have the same tendency, or is there something unusual compared to the results of the given study? As we know that elementary school students' thinking process begins to develop, and their' curiosity is very high. Therefore, researchers are interested in knowing the level of elementary school students' logical thinking ability.

\section{LITERATURE REVIEW}

Logical thinking is a way of thinking that is reasonable, coherent, and based on certain objective facts (Hadi, 2004). It can also be interpreted as the ability of students to draw legitimate conclusions according to the rules of logic and can prove that the conclusions are true based on their previous knowledge (Siswono, 2008). Logical thinking ability includes five types of reasoning, namely proportional, controlling variables, probability, correlational, and combinatorial (Inhelder \& Piaget in Wiji et al., 2014).

Logical thinking is to use a set of statements to support ideas systematically (Nuraida, 2014). Students who think logically will express ideas in linearly ordered words so that the construction of their arguments is correct. For students to reach the logical thinking stage, they should always be responsive in facing problems by answering the question "why, what, and how."

Capie and Tobin (in Sumarmo et al., 2012: 20) measure the ability to think logically based on the theory of mental development from Piaget through Test of Logical Thinking (TOLT) which includes five components, namely: controlling variable which is the ability to interpret information as a controller so that the relationship between independent and dependent variables is bound to be influenced by other things; proportional reasoning which is the ability of students to determine the quantity value based on a given proportion; probabilistic reasoning which is the ability of students to determine the likelihood of a particular event; correlational reasoning which is the ability to draw conclusions based on reciprocal relationships from the statements given; and combinatorial thinking which is the ability to determine the combination of an event.

Based on some of the explanation above, the researcher uses Piaget's theory of mental development through TOLT. Researchers use the five 
components of the test as an indicator in measuring students' logical thinking abilities. In controlling variable indicator the researcher gives 3 items about calculating distance and sorting values based on the statement provided. In the correlational reasoning indicator, the researcher gives 2 items about determining the value based on the relationship between variables. In the combinatorial reasoning indicator, the researcher gives 5 items about greatest common factors and least common multiple. In the proportional reasoning indicator, the researcher gives 5 items about ratio and proportion and the indicator of probabilistic reasoning has 5 items about chance and probability.

\section{RESEARCH METHOD}

This study applies a descriptive quantitative method. It is aimed at explaining existing phenomena by using numbers to describe individual or group characteristics (Syamsudin \& Damiyanti, 2011). Data obtained from the sample were analyzed according to statistical methods.

The subjects in this study were all students in Grade 5 from a public elementary school in Pekanbaru, Riau, Indonesia, with a total of 123 students consisting of 51 male students and 72 female students. The first step taken by researchers was to prepare a research instrument in the form of 20 items of logical thinking skill test. The teams discussed the items before testing them to the students.

Data analysis techniques are used to examine students' logical thinking. The data was processed using the quantitative data analysis. Data obtained from the results of students' logical thinking skills tests. A correct answer is given a score of 1 , and the wrong answer is given a score of 0 . The total score that has been obtained was then converted to a value in the range of $0-100$ by multiplying students' total score by 100 .

All test results were calculated using descriptive statistics, then analyzed descriptively, and conclusions were drawn. Data from students' ability to think logically are grouped according to the categories in table 1 (Arikunto, 2006).

Table 1. Categories of students' logical thinking ability

\begin{tabular}{cc}
\hline Value & Category \\
\hline $0 \leq X<20$ & Very low \\
$20 \leq X<40$ & Low \\
$40 \leq X<60$ & Medium \\
$60 \leq X<80$ & High \\
$80 \leq X \leq 100$ & Very high \\
\hline
\end{tabular}

After each student is categorized according to his logical thinking ability, then the researchers make a frequency distribution table so that the data that has been collected in large quantities can be presented in a clear and good form. Also, frequency distribution tables are 
made to simplify the form and amount of data so that when the data is presented, it will be easier to understand.

\section{RESULTS}

\section{Students' Logical Thinking Ability}

Students' logical thinking skills are obtained based on an analysis of 5 indicators namely, controlling variables, correlational reasoning, combinatorial reasoning, proportional reasoning, and probabilistic reasoning. Their logical thinking are categorized based on five level, namely very low, low, medium, high and very high. Students' abilities based on 5 indicators of logical thinking ability are shown in figure 1 .

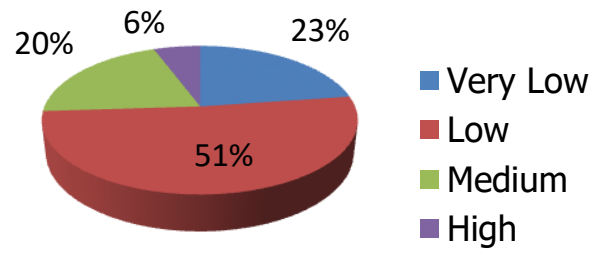

Figure 1. Students' logical thinking abilities

Based on Figure 1, More than $70 \%$ of students get very low and low categories. Overall, the average score of students' logical thinking was 29.84. Based on these results, students' overall logical thinking skills are still in the low category.

\section{Students Logical Thinking Ability in the Controlling Variable}

Figure 2 presents the students' logical thinking ability in the controlling variable. Most students are in the low category.

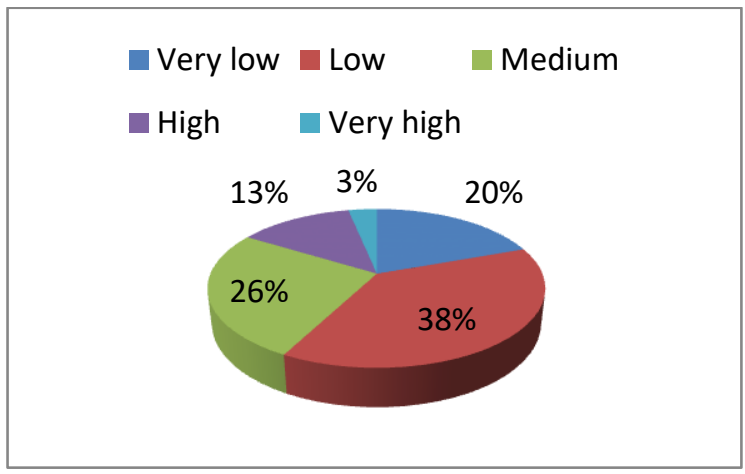

Figure 2. Logical thinking ability controlling variable indicators

Based on Figure 2, students who get very low and low categories are more than the students who get high and very high categories. There are no students in the medium category. The average value of students' logical thinking skills on this indicator is 38.48. Based on these results, students' logical thinking skills are in the low category. We present an example of students' work with the low category of controlling variable. We code the student as S83.

In figure 3, the task given to students is to order five students completed the national exam. Student $R$ scores higher than student $\mathrm{S}$, student $\mathrm{T}$ achieves the highest score, Student $U$ scores higher than student $R$, and student $\mathrm{V}$ sores lower than student $\mathrm{R}$, but higher than student $\mathrm{S}$. So, the task is 
to order students' score from the lowest to the highest.

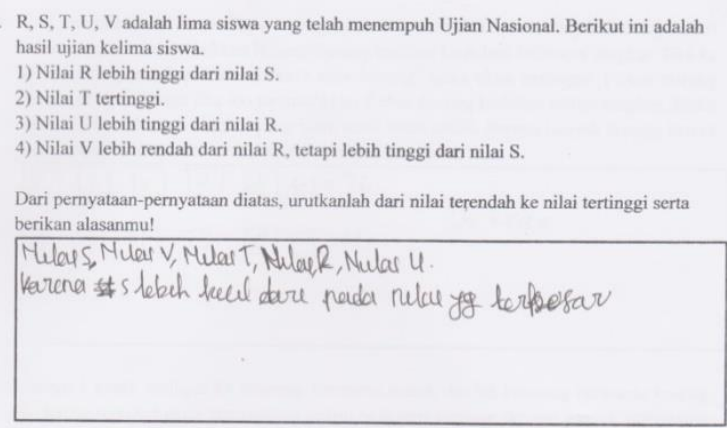

Figure 3. A question and an answer on the controlling variable indicator.

Student S38 gives an answer as student $S$, student $V$, student $T$, student $R$, and then student $U$ because student $S$ scores lower than the other students. Student S38 gives an incorrect answer because she put student $T$ in the middle while the task clearly mentions that student $T$ is the highest score. Although student S38 gives reasonable explanation, it does not help her to give the correct answer.

\section{Students' Logical Thinking Ability in the Correlational Reasoning Variable}

The correlational reasoning indicator in students' logical thinking skills shows their ability to determine whether two events or variables are related or not. The ability to determine the relationship between two events or variables can be seen in Figure 4.

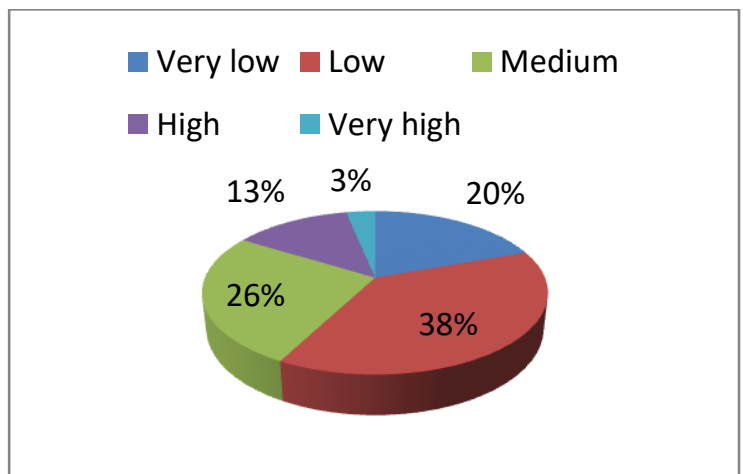

Figure 4. Ability to think logically correlational reasoning indicators

Based on Figure 4, students in the medium category get the highest percentage. There are no students with low or high categories. The average value of students' logical thinking skills on this indicator is 36.59. Based on these averages score, students' logical thinking skills are in the low category. Below is an example of questions and answers with a moderate category of correlational reasoning indicators represented by students S112.

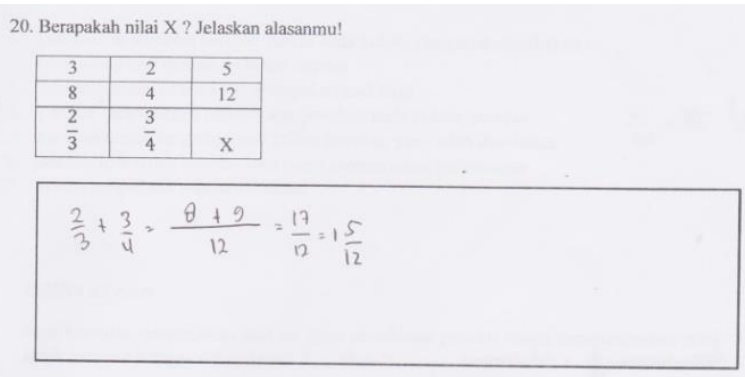

Figure 5. A question and an answer on correlational reasoning indicators

Based on Figure 5, students S112 gave a correct answerto the given task. He uses the concept of addition to get 
the value "X". The student also added both fractions correctly.

\section{Logical Thinking Ability in Combinatorial Reasoning Indicators}

The ability to determine a combination of events can be seen in figure 6 .

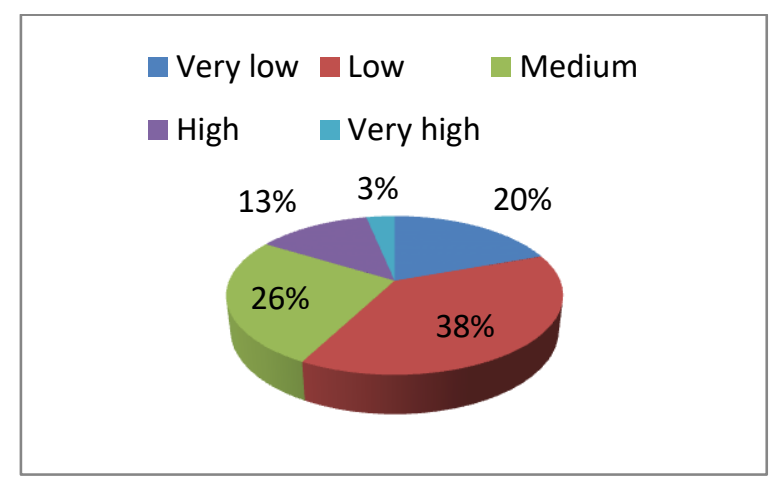

Figure 6. Ability to think logically combinatorial reasoning indicators

Based on Figure 6, students in the low and very low categories have a percentage of $70 \%$ more. Some students get a very high category with a percentage of $4 \%$. The average score of students' logical thinking skills on this indicator is 22.44. Based on these score, students' logical thinking skills are in the low category. Below are examples of questions and answers with a high category of combinatorial reasoning indicators represented by students S123.

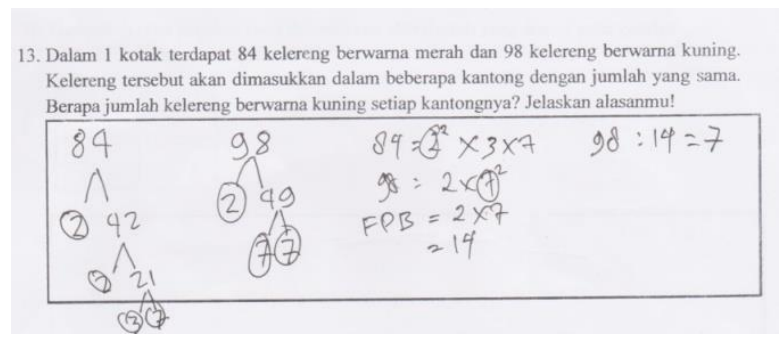

Figure 7. A Question and an answer on combinatorial reasoning indicators

Based on Figure 7, students S123 answered the task correctly. He can answer sequentially according to the data in the task. He used factorization to find greatest common divisor of each color of marbles, namely 84 red marbles and 98 yellow marbles.

\section{Logical Thinking Ability in Proportional Reasoning Indicators}

The ability to determine and compare ratios is presented in figure 8 .

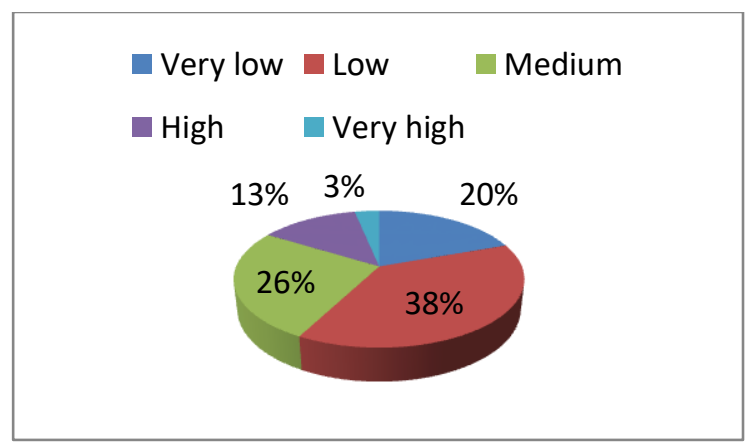

Figure 8. Ability to think logically proportional reasoning indicators

Based on Figure 8, there are various percentages from each category. In this indicator students who get a very high category are only 7 students with the 
smallest percentage of $6 \%$. The average score of students' logical thinking skills on this indicator is 30.73 . Based on this score, students' logical thinking skills are in the low category. Below are examples of questions and answers with high categories of proportional reasoning indicators represented by students S123.

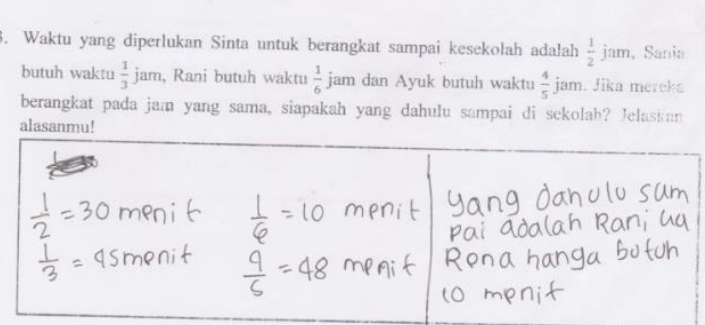

Figure 9. A question and an answer to the proportional reasoning indicators

Based on Figure 9, students S123 gave a correct answered by first changing the units of hours to minutes. After that, the student chose which of the answer choices that have smaller minute unit numbers, and according to him the smaller minutes indicate the fastest time to get to school. Students do not use the concept of proportional reasoning directly from the fraction numbers presented but changing it to the same unit.

\section{Logical Thinking Ability on Probabilistic Reasoning Indicators}

The ability to determine the likelihood of an event can be seen in figure 10 .

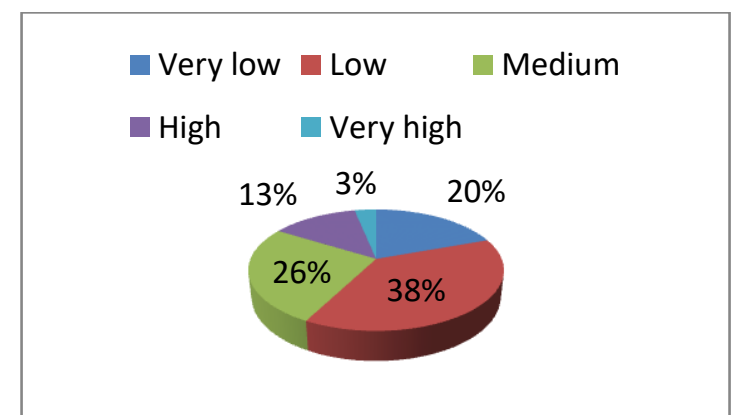

Figure 10. Logical thinking ability probabilistic reasoning indicators

Based on Figure 10, students in the very low and low categories get a percentage of more than $50 \%$. In this indicator, students who get a very high category are 4 students with a percentage of $3 \%$. The average score of students' logical thinking skills on this indicator is 28.78. Based on this score, students' logical thinking skills are included in the low category. Below is an example of a question and an answer with a medium category of probabilistic reasoning indicators represented by students S112.

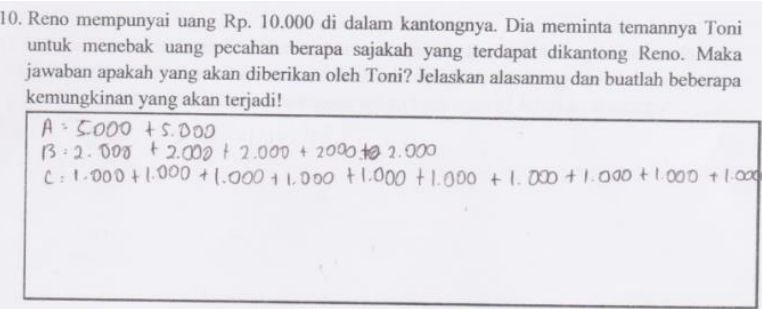

Figure 11. A questions and an answer to probabilistic reasoning indicators

Based on Figure 11, students S112 provided a correct answer by giving some possibilities that would occur if in the Reno pockets there was money of Rp. $10,000.00$. The possibility made by 
the student is to use the concept of multiples. The student only found three different combinations, and she did not figure out some combination of these numbers, for example, Rp. $5000.00+$ Rp. $2,000.00+$ Rp. $2000.00+$ Rp. 1000.00 .

\section{DISCUSSION}

Students' mathematical logical thinking skills are assessed from 5 indicators namely controlling variables, correlational reasoning, combinatorial reasoning, proportional reasoning, and probabilistic reasoning. From the analysis, we found that students' logical thinking skills are in the low category with an average of 29.84. The results of the analysis of the five indicators also get a low category with the lowest average value on the combinatorial reasoning indicator that is 22.44 and the highest average value on the controlling variable indicator is 38.48 .

The controlling variable indicator gets a low category with an average of 38.48. In this indicator, there are 3 items where some students only answer the questions without giving a logical reason. The correlational reasoning indicator gets a low category with an average of 36.59 . In this indicator, there are 2 items where most students answer without giving a logical reason. In the combinatorial reasoning, indicator gets a low category with an average of 22.44. In this indicator, there are 5 items in which most students answer incorrectly. The proportional reasoning indicator gets a low category with an average of 30.73 . In this indicator, there are 5 items in which only some students can answer by giving logical reasons. The probabilistic reasoning indicator gets a low category with an average of 28.78. In this indicator, there are 5 items where most students just answer without giving a logical reason.

When comparing to a study conducted by Octaria (2019), our study gives a lower result of students' logical thinking skills. Octaria's study showed that university students have moderate logical thinking skills on analytical geometry.

In connection with this study, students' logical thinking categories can be developed according to the growth of one's age and development of mindset. It is recommended that in the early stages of education that is the elementary school level students have begun to be trained in their ability to think logically by giving questions or tasks that bring students to think logically.

The low ability of students' logical thinking is caused by the student's mindset only focused on the formula given without understanding the concept of the formula so that when answering questions students are only able to 
answer correctly without knowing the process of getting it (Lely, Putra, \& Syahrilfuddin, 2020). In fact, in the ability to think logically students are not only required to answer correctly but are also able to provide logical reasons for how the results are obtained. This is reinforced by the results of interviews with students who represent high, medium and low categories. Students with high ability can express their reasons logically. But in this study, there was only 1 student who got a high category. Students in the medium category are only able to give most of the logical reasons while students who get the low category are only able to give a small portion of logical reasons in answering questions. This can be seen from the results where students with moderate and low ability answer the questions correctly but are unable to express reasons correctly. Also, students in the medium and low categories answered the questions by guessing and carelessly.

Cognitive development theory developed by Jean Piaget also said that students who were able to think logically and draw conclusions from available information were at the formal operational stage where the stage was ranked fourth with ages ranging from 12 years and up (Piaget, 2003). According to Piaget's theory, the student is still in the third stage, namely the concrete operational stage, with an age range of 7-12 years where students who are at this stage have started to reason but only with concrete objects (Piaget, 2003).

\section{CONCLUSION}

After calculating all students' scores classically the logical thinking ability of fifth-grade students is categorized as low, with an average score of 29.84 . Among the five indicators of logical thinking, the highest logical thinking ability is the controlling variable indicator and the lowest logical thinking ability is the combinatorial reasoning indicator.

Seen from each indicator, the controlling variable indicator gets a low category with an average score of 38.48, the correlational reasoning indicator gets a low category with an average score of 36.59, the combinatorial reasoning indicator gets a low category with an average value of 22,44 , the proportional reasoning indicator gets a low category with an average value of 30.73 , and the probabilistic reasoning indicator gets a low category with an average value of 28.78. From those indicators, it is obvious that there is high responsibility for teachers, teacher educators, curriculum developers, and government to develop learning instruction to support students' logical thinking because this skill is needed by students to face some challenge in $21^{\text {st }}$ century life.

The limitation of this research is the survey which was only conducted in 1 school. Further research needs to be done that examines more samples and involves private schools and distinguishes students' logical thinking skills from 
several variables such as gender, social status, and others.

\section{REFERENCES}

Andriawan, B. (2014). Identifikasi kemampuan berpikir logis dalam pemecahan masalah matematika pada siswa kelas VIII-1 SMP Negeri 2 Sidoarjo["Identification of logical thinking skills in solving mathematical problems in class VIII-1 Junior High School 2 Sidoarjo"]. Scientific Journal of Mathematics Education, 3(2), 4148.

Arikunto, S. (2006). Prosedur Penelitian Suatu Pendekatan Praktek [Research Procedure: A Practical Approach] Jakarta: PT Rineka Cipta.

Hadi, S. (2004). Metodologi Research jilid 3 [Research Methodology volume 3]. Yogyakarta: Andi.

Larson, L. C., \& Miller, T. N. (2011). 21st century skills: Prepare students for the future. Kappa Delta Pi Record, 473), 121-123.

Lely, M., Putra, Z. H., \& Syahrilfuddin, S. (2020). Fifth Grade Students' Creative Thinking in Solving OpenEnded Mathematical Problems. Journal Of Teaching and Learning in Elementary Education, 3(1), 58-68.

Nuraida, I. (2014). Implementasi Pembelajaran Student Explaning Untuk Meningkatkan Kemampuan Berpikir Logis Siswa SMA ["Implementation of Student Explaning Learning to Improve the Logical Thinking Ability of High School Students"]. Proceedings of the National Seminar on Mathematics
Education STKIP Siliwangi. Volume 2 Number 1.

Octaria, D. (2019). Kemampuan Berpikir Logis Mahasiswa Pendidikan

Matematika Universitas PGRI Palembang Pada Mata Kuliah Geometri Analitik ["Logical Thinking Ability of Mathematics Education Students at PGRI Palembang University in Analytical Geometry"]. Jurnal Pendidikan Matematika RAFA, $3(2)$, 181-194. https://doi.org/https://doi.org/10.19 109/jpmrafa.v3i2.1740

Piaget, J. (2003). Part I: Cognitive Development in Children--Piaget Development and Learning. Journal of Research in Science Teaching, 40(1), 8-18.

Siswono, T. Y. K. (2008). Model Pembelajaran Berbasis Pengajuan dan Pemecahan Masalah Untuk Mneingkatkan Kemampuan Berpikir Kreatif ["Learning Model Based on Submission and Problem Solving to Improve Creative Thinking Ability"]. Surabaya: Unesa University Press.

Sumarmo, U., Hidayat, W., Zukarnaen, R., Hamidah, M., \& Sariningsih, R. (2012). Kemampuan dan disposisi berpikir logis, kritis, dan kreatif matematik (eksperimen terhadap siswa sma menggunakan pembelajaran berbasis masalah dan strategi think-talk-write) ["The Ability and Disposition of Logical, Critical, and Mathematical Creative Thinking (Experiences of High School Students Using Problem-Based Learning and 
Think Talk Write Strategies"]. Jurnal Pengajaran MIPA, 171), 17-33.

Syafmen, W \& Marbun, R.H. (2014). Analisis Kemampuan Berpikir Logis Siswa Gaya Belajar Tipe Thinking dalam Memecahkan Masalah Matematika ["Analysis of Logical Thinking Ability of Students Learning Style Types of Thinking in Solving Mathematical Problems"]. Retrieved from

http://journal.unbari.ac.id/index.php/ JIP/article/view/127.

Syamsudin \& Damayanti. (2011). Metode Penelitian Pendidikan Bahasa ["Language Education Research Methods"]. Bandung: Remaja Rosdakarya.

Wagner, T. (2010). Overcoming The Global Achievenent Gap (online). Camridge, Mass., Hardvard University.

Wiji, W., Liliasari, L., Sopandi, W., \& Martoprawiro, M. A. (2014). Kemampuan Berpikir Logis dan Model Mental Kimia Sekolah Mahasiswa Calon Guru. ["Logical Thinking Abilities and Mental Models of School Chemistry for Prospective Teacher Students"]. Cakrawala Pendidikan, 33(1), 147-156. 